\title{
MINE RESCUE SERVICE. POLISH AND CHINESE EXPERIENCES
}

\author{
Piotr HETMAŃCZYK \\ Central Mining Institute, Katowice; phetmanczyk @ gig.eu, ORCID: 0000-0001-8816-6037
}

\begin{abstract}
Purpose: the main purpose of the article is to compare Polish and Chinese mine rescue services. It tries to bring closer the organization of mine rescue in Poland and in China and constitutes a development of the research work of the author's article entitled "Motivation to work in rescue services of young mining staff" (Hetmańczyk, 2017, pp. 19-24), indicating the main factors motivating young mining staff to work in the rescue services.
\end{abstract}

Design/methodology/approach: theses presented in the article have been verified using: literature review, critical literature analysis, document research and comparative analysis.

Findings: based on content of this article, it will be highlighted the need to seek new solutions to increase the efficiency of mine rescue. In the opinion of experts and practitioners in the area of security, the next "jump" may lead to the intensifying of preventive measures aimed at human beings, mainly focused on making changes in the consciousness of mining crews. In practice, this would mean including within the scope of preventive measures, those which have a major impact on the skills, motivation, and attitude to issues related to safe operation. Finally, the mine rescue system, through prevention and training, will strengthen safe mining practices.

Originality/value: the article enriches knowledge and develops discussion in the area of mine rescue. Thanks to the knowledge presented in the article, it can be concluded that role and the rank of mining rescue lies not only in the dimension of tasks that it has to perform, but also importantly in the dimension of new challenges that determine the need to constantly adapt mining rescue to dynamically changing organizational and technical conditions, both underground and on the surface of mine sites.

Keywords: human being; work; mine industry; rescue service; security.

Category of the paper: Conceptual paper.

\section{Introduction}

Underground mining is one of the most dangerous types of economic activity. Working conditions and safety in the mining industry are enormously impacted by natural hazards. The threats appearing here result, among others, from the characteristic of the working environment, the air mixture being different from the natural composition of the atmosphere, as well as the hydrogeological conditions. The history of mining is scarred by huge catastrophes 
with thousands of victims. The biggest include the disaster in the Chinese mine in Benxi (1942) resulting in the deaths of 1549 miners and in the French mine in Courrieres (1906), which killed 1099 people. The French disaster has become a source of intense research aimed at improving safety at work.

\section{Work safety in the mining industry - key determinants}

The security situation in the mining industry of a country, evaluated by the number of fatal accidents, is dependent on production volume and the number of employees in the industry. The key determinants of safety in the mining industry are trained crews, the quality and quantity of equipment and the identification, monitoring and control of risks.

One of the crucial factors of work accidents is the volume of production. The ten largest producers of coal (coal and lignite) in 2017 in million tons of oil equivalent are as follows (Coal Production. BP Statistical Review..., 2018):

1. China - 1747.2.

2. US -371.3 .

3. Australia - 297.4.

4. India - 294.2.

5. Indonesia - 271.6.

6. Russian Federation - 206.3.

7. South Africa - 143.0.

8. Colombia - 61.4.

9. Poland -49.6 .

10. Kazakhstan -47.9 .

Statistics of the International Labour Organization (ILO) report on the number of fatal accidents. Accordingly, in 2017 in Australia - 3 workers were killed, in the US - 15, in India 33, in Poland - 10 (ILO Database, 2019), and in China - 375 (State Administration of Coal Mine Safety, 2019; Stanway, 2019). It is clear that the number of deaths is not strictly related to extraction amount. Persons employed in mines are exposed in the course of mining works to various threats. Two of the main threats in the mining industry are the risks of fire and explosion. It is necessary to take appropriate precautions to prevent fires and, if they occur, to ensure they are extinguished quickly and effectively. When an accident or unusual event occurs in the mining plant, mine rescue services are available to help.

Mine rescue provides assistance to miners and mines threatened by the effects of random events (underground fires, explosions, subsidence), and restores safe working conditions after an accident. Mine rescue also consists of preventive action and training activities. The increase in mining hazards and the observed fatal accidents at work has led to an enhancement of the 
requirements of the rescue services, not only in terms of their numbers, but also the effectiveness of their training and exercises, as well as an increased equipment and technical base (Hetmańczyk, and Martyka, 2015, pp. 126-132; 2017, p. 11).

The main component of any rescue system is the human being: the rescuer - a specialist with unique and constantly improving qualifications. Considering the fact that the operation is carried out at increasingly greater depths which entails increased hazards, the reliable operation of the rescue system must be ensured.

\section{The institutional basis of mine rescue in Poland}

Polish mine rescue activity has over one hundred years of history. It was established (as previously mentioned) in the aftermath of a disaster in the French mine in Courrieres. Currently, the Polish mine rescue system may take intervention measures in each case of a random event underground, in a borehole and in surface mines. Additionally, it is able to provide prevention activity, protecting people and workstations against the effects of phenomena that threaten their safety.

The organization and functioning of modern mine rescue services in Poland is regulated by the Act of 9 June 2011 "Geological and Mining Law" (Ustawa..., 2011) and the Regulation of the Minister of Economy of 12 June 2002 on mining rescue services (Rozporządzenie..., 2002).

Mining supervision authorities, which consist of the President of the State Mining Authority, the directors of the regional mining authorities and the directors of the Specialized Mining Office, supervise and carry out inspections of entities dealing professionally with rescue operations in mines.

The structure and system of mine rescue are the result of lengthy evolution, taking into account the specificity of conducted rescue operations, its analysis, as well as the changing state of safety in mines. Mine rescue covers the entire Polish mining industry (coal, ore, oil and gas, chemicals and construction raw materials). In each individual mine, rescue teams and adequately equipped mine rescue stations or mine rescue points are in operation. The rescuers employed in mines are the miners performing their daily duties - there are about 6 thousand people. As part of mine rescue teams, there are also specialized groups that require special skills (underwater, drilling, working in vertical and steep slopes). Professional mine rescue is performed by three units: the Central Mine Rescue Station SA (CSRG) in Bytom, the Borehole Mining Rescue Station (RSGO) in Krakow and Mine and the Steelworks Rescue Unit (JRGH) in Lubin.

CSRG is a public company and the State Treasury is its shareholder. CSRG is entrusted with the execution of public tasks, involving taking part in carrying out rescue operations and helping mining plants to prevent mining hazards and remedy the consequences of those that 
occur. It performs its tasks with the assistance of specialized mining services, which consist of the emergency rescue team on duty in the regional mine rescue stations. The organizational structure of the CSRG as mine rescue units is made up of four Regional Mine Rescue Stations in Bytom, Jaworzno, Wodzisław Sl. and Zabrze (OSRG). In order to carry out statutory tasks, CSRG maintains regional stations permanently through daily shifts of rescue teams, which comprise of: a rescue group manager, ten mine rescuers and a rescue equipment mechanic. At the request of a mining plant, groups are equipped with appropriate equipment and means of transport. CSRG rescue groups on duty during a rescue operation are provided with medical care by doctors of the mine rescue service. CSRG protects coal mines, salt mines and mines extracting other raw materials. What is noteworthy is that the core business of CSRG is carried out in three categories: intervention activities, preventive activities, and training activities.

Rescue operations are organized within the framework of intervention, in order to save lives and protect the health of miners and disaster restoration and safe working conditions after the occurrence of unforeseen events. In 2014, CSRG participated in eight rescue operations associated with underground fires and the evacuation of victims from mine workings. In addition, specialized professional emergency rescue teams participated in 171 rescue operations, including 77 involving work related to the control of brickwork equipment and mine shafts state. The rescue services of CSRG, in the framework of preventive activities, in 2014 conducted 154 planned rescue operations without the participation of specialized emergency services, primarily related to the opening, ventilation and penetration of inactive workings and the monitoring of refractory expansion tanks. As part of the training activities, which consist of organizing training, which stem from the Regulation of the Minister of Economy on mine rescue (OJ No. 94, item. 838, 2004), in 2014, 5767 people took part in compulsory courses, and 876 people in additional courses.

\section{The formal and legal basis of mine rescue in Poland}

Article 75, paragraph 1 of the Act Geological and Mining Law provides an obligation of a mining entrepreneur to have organized mine rescue and to ensure constant opportunities for participating in the rescue action of specialized professional services, such as CSRG or another entity professionally engaged in carrying out activities in the field of mine rescue. In this context, it is in the interests of the entrepreneur to provide a high level of rescue protection. This is of particular importance due to worsening mining and geological conditions in the mines. This premise should take into account, among others, extending the catalog of preventing work performed by rescue groups with works carried out in high-risk areas as specified in the mine safety document. 
In turn, the profession of mine rescuer and equipment mechanic is included in the Regulation of the Minister of Internal Affairs and Administration of 6 April 2004 concerning the adaptation period and aptitude test in the course of proceedings on the recognition of the qualifications to perform mining regulated professions in European Union countries (OJ No. 76, item. 725 of 23.04.2004). The Minister of Economics in the Regulation of 15.12.2005 established the principle of ascertaining the qualifications of managers and specialists employed in entities professionally engaged in carrying out activities in the field of mine rescue services (OJ No. 261, item. 2186). According to regulation, the requirements to act as rescuers are very high. Fulfilling these requirements need an extensive level of abilities, skills and experience.

The Minister of the Economy in the Regulation of 12 June 2002 on mine rescue (OJ No. 94 of 2002, item. 838, as amended) specifies the requirements that applicants must meet in order to work in the rescue service.

$\S 28$. A mine rescuer can be a person who:

1) is twenty-one years old,

2) has worked for at least 12 months in the mining plant in a given specialty,

3 ) has an adequate health status and adequate psychological predispositions, confirmed by specialized research,

4) completed the basic course for candidates for mine rescuers and passed the exam with a positive result,

5) knows spoken and written Polish, to the extent necessary for mine rescuer activities.

\$29. A rescue equipment mechanic can be a mine rescuer or former mine rescuer who:

1) has completed at least vocational school,

2) has an rescue internship of not less than five years, and has worked in plant looking for oil and natural gas and the mineral-extracting industries through drilling for not less than 3 years,

3) completed the basic course for candidates for rescue equipment mechanics and passed the test with a positive result, knows spoken and written Polish, to the extent necessary for rescue equipment mechanic activities.

In accordance with the above paragraphs, rescuers must be workers with good health and exceptional qualifications, which often support rescue actions. It is worth noting the relative youth of potential candidates for mine rescuer - often considered as too low (Martyka et al., 2011, pp. 14-21). 


\section{The institutional basis of mine rescue in China}

According to Onet.pl, in the past ten years, coal mining in China has almost doubled and the number of fatalities has decreased during this period by 80 percent (Onet.pl, 2018). Coal is an important energy source in China as it constituted over $60 \%$ of Chinese primary energy consumption during the period 2001-2010 (Xie et al., 2013, pp. 11-15). In China, almost $90 \%$ of the total coal production comes from underground mining. Deep mines and mines with high concentrations of gas and high groundwater pressure are associated with high accident rates (Sui, 2013, pp. 563-567; Sui et al., 2011, pp.735-749). The average depth of coal mining in Chinese mines was approximately $700 \mathrm{~m}$ in 2010, and the deepest exceed $1200 \mathrm{~m}$. Additionally, more than half of the mines are situated in formations which have high gas concentrations. From 2001 to 2012, Chinese coal mines recorded 30848 accidents, which killed 51232 people (Chen et al., 2012, pp. 745-750). These statistics confirm that the coal industry in China is, like in Poland, a high risk industry.

Due to this situation, the Chinese government has taken actions to improve and develop mine rescue. This has been based on strategic planning in the field of six support systems that have been developed by the State Administration of Work Safety (SAWS) and the State Administration of Coal Mine Safety (SACMS). Thanks to these actions, the rescue operation mechanism has been brought up to date. Currently, the mine rescue system plays an important role in mine rescue, legal system construction and international exchange.

Once the People's Republic of China (PRC) was formed, based on relevant work safety laws and regulations determined by the Chinese government, mine entities began to form rescue teams. In addition, some large coal mining cities and counties created mine rescue teams within their coal industry management departments. Currently, China has 76 mine rescue brigades, 449 medium-sized teams and 1445 rescue teams. There are 14328 rescue personnel directly involved in mine rescue (Zhijian, 2011).

PRC gives special importance to the technical training of rescue personnel in mines. Every year, each province and region of PRC carries out technical training courses aimed at improving professional skills in mine rescue. The central government and local authorities invest annually in mine rescue equipment and its renewal.

Mine rescue management in PRC has been undergoing changes. Since 1994, PRC introduced a management system of mine rescue based on district brigades and mediumsized auxiliary teams in mine rescue. In 2002, the State Council of PRC has defined responsibilities for organizing, directing and coordinating mine rescue and emergency rescue. These duties were taken over in 2002 by the aforementioned SAWS and SACMS. Based on the above, it can be seen that in PRC a functioning mine rescue system has been implemented. 


\section{The formal and legal basis of mine rescue in China}

Since 1956, the Ministry of Coal of the PRC has issued a number of legal acts regulating mining industry management, including: in 1978 "Rules of Mine Rescue Team Work" and "Fighting Preparative Criteria and Inspection Method of Mine Rescue Team". In 1987, the Ministry of Coal re-issued "Mine Rescue Regulations", "Fighting Rules of Military-like Mine Rescue Team" and "Management Method of Military-like Mine Rescue Team". Then the Ministry of Energy of the PRC improved regulations. In 1993 and 2002, the PRC developed and implemented "Mine Safety Law of the People's Republic of China" and "Work Safety Law of the People's Republic of China" (Chinaming.org, 2019).

Despite these regulations, problems still exist in Chinese mine rescue. The following are of particular importance:

- A lack of a general plan for the establishment and arrangement of mine rescue operations and rescue organizations. Most medium and small coal mines and non-coal mines do not have mine rescue teams. In addition, most villages, towns and private mines do not have the support of mine rescue teams.

- There is no unified and coordinated mine rescue system or mechanism for its creation. Each existing mine rescue team works in its own way, which not only depreciates its resources, but is also not favourable for a successful rescue.

- A lack of rescue funds. Rescue equipment is outdated. There is no clear communication and there is a lack of a stable rescue department. Rescue employees are aging and of dubious quality. The general efficiency of rescue teams is diminishing.

According to the requirements of mine work safety and mine rescue tasks, SAWS and SACMS decided to consolidate existing rescue resources. The main objectives of the consolidation were to base mine rescue on local government and mining enterprises, combining local management with central command and coordination, to create an emergency mechanism that would coordinate rescue operations at various functional levels.

The mine rescue system works in accordance with the following organizational chart: State Mine Rescue Command Center (SMRCC), Mine Rescue Command Organization at Provincial level, Emergency Rescue Management Department at Municipal and County level and Emergency Rescue Management Department in a mine. SMRCC was founded in 2003. It is responsible for:

- organizing and coordinating mine rescue across the whole country,

- the preparation of mine rescue regulations, dissemination and use of new mine rescue technologies and equipment,

- mine rescue competitions across the country,

- qualification assessment of mine rescue groups,

- organization of technical training courses and international exchanges,

- cooperation in projects in the field of mine rescue. 
SMRCC supervises the Mine Rescue Command Organization at a Provincial level and is responsible for drawing up emergency plans of mine safety and rescue in local regions, as well as organizing, directing and coordinating rescue work and mine rescue recommendations. Currently, in the PRC there are eighteen provincial mine rescue command centers. Other centers at provincial level have also been created. Mine rescue command departments in large cities and mine counties are responsible for organizing and coordinating mine rescue in their region. Their activities are directed by higher level emergency rescue department. Emergency Rescue Management Departments in the mines are responsible for the organization of its own rescue by creating an emergency rescue plan, monitoring rescue devices, reserving materials and organizing emergency rescue training courses.

\section{Summary}

Mine rescue has a special place in the safety system of mine. The reason for this is the ever-present possibility of crisis situations occurring that lead to risks to health and life, and come about as a result of human error, natural causes or defective devices. Mastering crisis situations is not possible without the participation of "rapid response rescue teams". Hence, the role and rank of mine rescue lies not only in the tasks it has to perform, but also, significantly and perhaps even more importantly, in the psychology of miners, as an inner belief that rescue will happen.

A summary of similarities and differences between Polish and Chinese mine rescue is presented in Table 1.

Table 1.

Similarities and differences between Polish and Chinese mine rescue

\begin{tabular}{|c|c|c|}
\hline & Poland & PRC \\
\hline Legal Regulations & $\begin{array}{l}\text { - Act of } 9 \text { June } 2011 \text { "Geological and Mining } \\
\text { Law" } \\
\text { - Regulation of the Minister of the Economy } \\
\text { of } 12 \text { June } 2002 \text { on mining rescue services } \\
- \text { Subsequently defined regulations of entities } \\
\text { professionally dealing with mine rescue }\end{array}$ & $\begin{array}{ll}- & \text { Coal Law } 1996 \\
- & \text { Work Safety Law } 2002 \\
- & \text { Mining Safety Regulations } \\
& 1996\end{array}$ \\
\hline $\begin{array}{l}\text { Administrative } \\
\text { agencies }\end{array}$ & State Mining Authority (WUG) & $\begin{array}{ll}- & \text { State Administration of Work } \\
& \text { Safety (SAWS) } \\
-\quad \text { State Administration of Coal } \\
\text { Mine Safety (SACMS) }\end{array}$ \\
\hline $\begin{array}{l}\text { Fatality rate (number of } \\
\text { fatal accidents per } \mathrm{Mt} \text { ) }\end{array}$ & 0,20 & 0,21 \\
\hline Number of rescuers & 6000 persons & 14000 persons \\
\hline
\end{tabular}

Note. PRC - People's Republic of China. Source: own study. 
It is noteworthy that in both countries the mine rescue system is based on a similar number of legal regulations. However, it is worth emphasizing the earlier regulation on safety in mines in the PRC. The mining supervision authority, which performs and regulates entities involved in rescue operations in mines, in Poland is the State Mining Authority. In PRC, there is no single supervisory authority. The responsibility for the supervision and control of mines was divided into two entities: the State Administration of Work Safety and the State Administration of Coal Mine Safety. The fatality rate per million tons of coal in 2016 in Chinese coal mines was 0.31 and this was almost twice as high as in Poland. However, the Chinese death rate has steadily decreased since 2001. Indeed, as of 2016, it had decreased by $90 \%$ when compared to 2001. In the same period, the fatality rate per million tons fell by $42 \%$ in Poland. The number of rescue personnel in China is more than twice as high as the number of Polish rescuers.

In conclusion, the presented statistical data should highlight the need to seek new solutions to increase the efficiency of mine rescue. In the opinion of experts and practitioners in the area of security, the next "jump" may lead to the intensifying of preventive measures aimed at human beings, mainly focused on making changes in the consciousness of mining crews. In practice, this would mean including within the scope of preventive measures, those which have a major impact on the skills, motivation, and attitude to issues related to safe operation. Finally, the mine rescue system, through prevention and training, will strengthen safe mining practices.

\section{References}

1. Chen, H., Qi, H., Long, R.Y., and Zhang, M.L. (2012). Research on 10-year tendency of China coal mine accidents and the characteristics of human factors. Safety Science, 50, 745-750.

2. Chinamining.org, Law of the People's Republic of China on Safety in Mines - China Mining, 7 August 2006, http://www.chinamining.org/Policies/2006-08-07/1154932041d 472.html, 19 April 2019.

3. Coal Production (2018). BP Statistical Review of World Energy.

4. Hetmańczyk, P., and Martyka, J. (2015). Ocena społecznego odbioru procesu restrukturyzacji zatrudnienia $\mathrm{w}$ górnictwie węgla kamiennego (Assessment of public perception of employment restructuring process in hard coal mining). Wiadomości Górnicze, 3, 126-132.

5. Hetmańczyk, P., and Martyka, J. (2017). Ogólna charakterystyka zagrożeń w górnictwie węgla kamiennego w 2016. In: J. Kabiesz (ed.), Raport roczny o stanie podstawowych zagrożeń naturalnych $i$ technicznych $w$ górnictwie węla kamiennego (General characteristics of hazards in coal mining industry in 2016. Annual report on the state of basic natural and technical hazards in coal mining industry. Katowice: GIG, 11. 
6. Hetmańczyk, P. (2017). Motywacja do pracy w służbach ratowniczych młodych kadr górniczych (Motivation to work in rescue services of young mining staff). Bezpieczeństwo Pracy i Ochrony Środowiska, 3, 19-24.

7. ILOSTAT database. Available at: http://www.ilo.org/ilostat/faces/wcnav_default Selection?_afrLoop=2066453419325455\&_afrWindowMode=0\&_afrWindowId=10is7qp 0lg_42\#!\%40\%40\%3F_afrWindowId\%3D10is7qp0lg_42\%26_afrLoop\%3D20664534193 25455\%26_afrWindowMode\%3D0\%26_adf.ctrl-state\%3D10is7qp0lg_86, 11 April 2019.

8. Martyka, J., Majer, M., and Nowak, K. (2011). Jak się zostaje ratownikiem górniczym? Wyniki sondażu (How do you "become" a mining rescuer? Results of opinion poll). Bezpieczeństwo Pracy i Ochrony Środowiska, 12, 14-21.

9. Onet.pl, Chińska delegacja w Katowicach - rozmawiano o bezpieczeństwie w górnictwie (Chinese delegation in Katowice - talks focused on safety in mining industry), https://slask.onet.pl/chinska-delegacja-w-katowicach-rozmawiano-o-bezpieczenstwie-wgornictwie/jxve0d, 11 April 2018.

10. Rozporządzenie Ministra Gospodarki z dnia 12 czerwca 2002 r. w sprawie ratownictwa górniczego (Dz.U. Nr 94, poz. 838, z 2004 r.). Regulation of Minister of Economy of 12 June 2002 on mining rescue services (OJ No. 94, item. 838, 2004.)

11. Stanway, D. China workplace deaths fall to 38000 in 2017: report. Reuters. Available at: https://www.reuters.com/article/us-china-safety/china-workplace-deaths-fall-to-38000-in2017-report-idUSKBN1FJ05C, 19 April 2019.

12. State Administration of Coal Mine Safety. Available at: http://www.chinacoalsafety.gov.cn/xw/yjglbyw/201802/t20180206_202932.html, 11 April 2019.

13. Sui, W.H., Liu, J.Y., Yang, S.G., Chen, Z.S. and Hu, Y.S. (2011). Hydrogeological analysis and salvage of a deep coalmine after a groundwater inrush. Environment Earth Sciences, 62, 735-749.

14. Sui, W.H. (2013). Safety geology and geological education for mining engineers. Global View of Engineering Geology and the Environment. Wu, F., and Qi, S. (eds.). Boca Raton, FL: CRC Press, 563-567.

15. Ustawa z dnia 9 czerwca 2011 r. "Prawo geologiczne i górnicze" (Dz.U. poz. 1131 z 2016 r.) Act of 9 June 2011 "Geological and Mining Law" (OJ 1131, 2016.)

16. Xie, H.P., Liu, H., and Wu, G. (2013). China's coal industry must follow the path of sustainable production capacity. Official Journal of the World Coal Industry, 11-15.

17. Zhijian, W. (2011). China's mine rescue system and development of mine rescue. The 5th International Mine Rescue Conference, Beijing, 24 October. 